\title{
Opportunities at Higher Education Institutes in India: Small Cases on Enhancing Skills
}

\author{
Ranjana Kothari
}

\begin{abstract}
This article basically tries to explain that opportunities are the key to success and how students can take advantage and learn new skills or to enhance existing ones. it is an understanding of the opportunities and using the strengths in the right way which in turn helps in achieving better. Higher education institutes provide platform to every individual, and can seek opportunities not just by looking at what he/she can do but rather he/she must be built in such way that they can recognise or analyse how he/she can use the resources or qualities that they already have within them or may build. This article is based on some case studies done on students of Amity University Haryana, India. And found how their personality changed during their degree at institute in terms of enhancing skills through opportunities. These students are always very positive in approach and were keen to learn and do something better for country.
\end{abstract}

KEYWORDS-Opportunities, positive, Strengths and weaknesses, skills

\section{INTRODUCTION}

Understanding the opportunity, taking it positively is a process by which individuals and organizations obtain, improve, and retain the skills, knowledge, and other resources needed to do their jobs competently. It also allows individuals and organizations perform at a greater capacity. Opportunity is a specific time or specific circumstances that make possible to do something. It is like a chance to be utilized for a purpose. According to $\mathrm{T} T$ Train [4] skill enhancement is not only most essential part during their study, but also for success in career, growth and personal level. And these skills must include problem solving, the ability to effectively problem solve is a highly valued competency expected among graduates, independent of their area of study given by A Klegeris, et al.[3].

Manuscript received May 23, 2020

Ranjana Kothari, Associate Professor, Amity Business School, Amity University, Haryana, India (email: ranjana.kothari77@gmail.com)
Leadership comes from identifying opportunity and the leaders and managers from these higher educational institutions learn all their roles, share responsibility with formal and informal leaders from faculty and staff groups, and recognize change [2]. The study done by M Clarke[1] aimed to consider the extent to which individuals in this group had adopted opportunities supportive of future employability as opposed to behaviours more in line with traditional careers. This paper emphasis on how one can work on with their strengths instead of always trying to improve their weakness. In this paper the author has presented three student's case studies. These students are the one who always believed in their strengths and used them in a right way. These students believed in creating a better pavement to their future by focusing on opportunities that made their strengths stronger. The students belong to Amity University.

These students can be called the path changers.

Following are the studies:

\section{A. Case 1:}

\section{“Creating opportunities through strengths"}

The story of Sonu's childhood is almost stereotypical; being a young boy can be both an adventure and a challenge, fighting for acceptance amongst other kids of his age, trying to find his place in the face of incessant bullying, an immature identity, and teenage insecurities. It is to defeat these challenges through opportunity and guidance that has grown him into a leader, choosing the harder path and taking initiative that taught him the experience of success and equally as important his failures.

Being bullied might be the hardest part of being a child. After facing isolation from other kids, he found solace in technology, accessing a trove of knowledge that is the internet. Through making friends over internet communities, he developed a passion for gaming, information technology, coding, and graphic design. For him these hobbies were almost an escape, finding passion in creating art through his computer. It was at this phase that he was asked by one of his teachers, and to be mentor, to design a poster for his charitable foundation that found young students to help educate the underprivileged in the state of Bihar, implanting in him a love of social work; and starting his journey of constant initiative that would one day drive him up the ranks. The importance of teaching leadership at a young age is no more apparent. His mentor 


\section{Opportunities at Higher Education Institutes in India: Small Cases on Enhancing Skills}

recognizing his potential encouraged him to join the Scouts, building in him an attitude that helped him fend off bullying, teaching him to lead and speak through responsibility, and embedding in him a sense of duty and discipline. He used his passion for computers to implement systems and organization that helped grow and professionalize his local Scouts \& Guides movement, eventually graduating high school as a competent leader who spent his mornings as a student, evenings as a leader in the Scouts, and nights working for his mentor's charitable foundation.

After school his passion for work and initiative to innovate didn't end, taking a gap year to explore himself, increasing his responsibilities with charities, and taking up part-time management jobs to enrich himself with experience; eventually being part of teams that broke 2 Guinness World Records that year amongst countless other projects in charity and events. Self-learning became an important part of his life, where he made up for missing skills by teaching himself through books and the internet, and then practicing what he learnt on the next project, becoming an ace-of-all through an incessant passion for improvement with every challenge When it came time for him to go to college, the principles of giving-back, society, and empowerment were deeply engrained in him; immediately planning his next step on the world's stage to share what he'd learnt through his life experience by empowering his fellow youth to become capable leaders, the same way he was given a chance once before. Starting with his first semester in college, he gathered a few friends that came up with a little club called Saakar, tackling grassroots social issues in healthcare, education, and women's rights. Little did he know that his constant push to dream bigger, help fellow young minds like him to find their purpose and potential, and an undying spirit would turn Saakar into a platform for youth to become leaders and change-makers? With a strong set of goals of not only doing social work and community service, but equally focusing on the emotional needs, personal, and professional development of his peers, is what turned Saakar from a college club into an ideology, an ideology where young people can be empowered through experience as they serve their country-men, eventually leaving them as capable, confident, and skilled change makers who would find success in their professional lives, deal better with personal and emotional problems, and build a caring citizen.

Leadership is truly the shortcut the success, and as far as Sonu goes, success is only worth celebrating when it is shared amongst his people. The impact he, his team, and thousands of young students that their once simple initiative has touched is immeasurable, turning his leadership into an almost infectious passion that his peers look up to, taking it forward wherever in life they go. Leaders are made, and not born, and it is through creating opportunity for yourself is where leadership starts. Taking his personal challenges of being a young boy and turning them into a motivation to learn and succeed is no better proof in the power of self- empowerment. Sonu's story is an example for how he created his opportunity with his leadership skills.

\section{B. Case 2:}

\section{"It is just not grabbing opportunities rather it is moldings} accordingly with strengths"

The story of Hiranya is more like a maze. She made odd choices according to the others but she is someone who chose want she can really do. She did not magnify the weaknesses that she holds but rather she started using the strengths to pursue better. According to her goal setting is not setting a career rather it is choosing how one want to see their self in future. She said that her goal was always clear and only the way of reaching it kept changing according to the situations, surrounding and opportunities she found. She is very emotional and empathetic girl. Unlike others she turned her characteristics like being emotional and sensitive as her strengths. Her life is a perfect example of grabbing every opportunity and molding it according to her convention. As a school going kid, Hiranya was above average student in academics but as she entered her graduation she excelled in her academics and co-curricular skills. She used every opportunity for exposure and acquiring knowledge. Today, she got admission into UoL under academic direction of London School of Economics and political science. Hiranya is a diligent, learner, curious, good observer, good leader, dynamic speaker and analyzer. From her childhood days she has a quest towards questioning the impossibilities and find answers to them. This made a pavement towards her interest in reading books and writing articles. Hiranya pursued her senior secondary in subjects Biology, physics and chemistry as core. Her passion was to become a doctor. But later she realized that her strengths and weakness have a better place to fetch her. She recognized her leadership, communication, management and organizing skills. Then she got into Bachelor in Business Administration at Amity. As told before she never took a chance of missing any opportunity. One month later after joining Amity, she grabbed a chance of going to USA for cultural exchange program. She took this chance to a next level by publishing her first research paper at the age of seventeen. She is one of the pro active students in the university. She used her creative, spontaneous and oratory skills to build herself. During her final year of study she observed that the demand for data science is growing and it is something she is capable of doing. She focused on her logical, analytical and reasoning skills and chose the stream. People thought she cannot make it as it is a complete different stream. They felt she is making an insane decision and cannot make it. She didn't only make it rather she made into a world's one of the top most college for her PGDM in Data science. An ordinary girl from Johnson Grammar School, Hyderabad to an extraordinary girl who is into UoL Hiranya sets an example for polishing strengths using every opportunity for better future. According to her everybody is imperfect and everyone is perfect in their perfects only. She adds that there is no size for opportunity and any opportunity that 
adds a minute difference to your future is a huge one. She believes that to be successful one need not to be good in all aspects but have to be good at what they can do.

\section{Case 3:}

\section{"Being introvert to a director"}

Today we see Deepak Bajaj, as a highly confident and competitive personality, a man who loves meeting and beating the expectations people have with him. He is been remembered as the Founder of the Amity's Dramatic Society Ek Awaaz, that kept on establishing new milestones right from its inception, in the field of theatre. This gentleman who started from the very scratch, leading different roles under challenging settings as an actor, as an orator, as a performer and ultimately to a director, had created his own strong identity not just by developing new skills but by grabbing new opportunities. It would be strange to know that this man, who never misses an opportunity on stage today, had stepped up on it for the first time in his life during his orientation ceremony at Amity University Gurugram. During his schooldays, he was a boy who was always hesitant in interacting with new people thinking they will make fun of him. Forget about a performance, he used to hide himself in a corner whenever his name was called off. But those opportunities that he grabbed his way changed his life forever.It is still remembered, the first reward he had received was a just a mere Rs 5 chocolate, but it have him such a boost, that he registered himself for Mr Fresher competition, which was a huge platform for him. Unfortunately, he could not make to college one day and failing to appear for one of the rounds, made him got out of the competition. But that disappointment had been a life changing experience for him that made him realize that time and opportunity will wait for none, if he wanted to prove his worth, he will have to make his own way out. Rather than getting away from his weaknesses, why shouldn't he try to overcome those by grabbing new chances? While hunting for a new opportunity, being a Btech student, rather than loving his machines, he developed a love for theatre. But sooner or later, he realized, to bring about that change, he needs a team. When the other students were trying to settle down in the new atmosphere, he began his hunt for the Amity's first Dramatic Society. Slowly and gradually, they started winning competitions and making their own way out among the rest thousands of students and soon he became the Director of Amity's First every Dramatic Society "Ek Awaaz". But as we all know, street play callings were never a part of Amity's culture and so as the students. The more they performed, the more he was criticized. Although the college authorities had developed a trust factor on this guy, the higher authorities and all the teachers used to support him, but again he was never satisfied. He wanted to make his way through the hearts of the students and the hunt for another opportunity began soon. And there it was a chance to represent Amity at the India's biggest fest, The Nokia
Lumia VFest 2014 in Goa and Deepak became the first student of Amity to represent himself on such a huge platform. He became the best actor all over Delhi and stood $5^{\text {th }}$ all over India. He kept on progressing and so as his greed. His strive towards excellence, made him won a no of titles such as Delhi Rockers 2014, Talent Baaz 2014 and it went on and on. A time when he was at the peak of his journey, his achievements could speak louder than his words. The icing on the cake was receiving the Cultural Achiever Award by the "Rajasthan Royals Team". Those opportunities that he grabbed during his way, made him a changed personality altogether. And in that urge to do something different, he made various collaborations with corporate hubs, NGO's, Government bodies, and much more that turned those 'Nukkad Nataks' into 'Paid Performances'. Ek Awaaz had flooded almost everywhere and not even him, the amount of confidence that all the team members had among themselves, made them excel in all the fields. Proving himself as a good manager, from team management, he now stepped into Event Management and started managing almost all the events in the University campus. He grabbed each and every opportunity available in front of him and turned the things in his favour. Along with, he started participating in debates, poetry competitions, emerged out as an anchor and was able to realize his creative part that way. From a lonely and shy guy, he turned out to be a strong and dependable leader. That friendship changed into a bond, that team changed into a family, criticism got converted into applauses and that little boy Deepak today is proudly remembered as Deepak Bajaj.

\section{CONCLUSION}

In these three cases we can observe how the individuals used their strengths for creating better things. They used every opportunity that they found and created their opportunity where they can exhibit their strengths. They chose roads that were less often travelled. They had numerous hurdles and they time they passed they took lessons with them. Deepak's story tells us how he suppressed his weakness using his strong traits. Sonu's story shows how he created his opportunity. Today his opportunity is giving many more youngsters like him an opportunity to be the change makers. While Hiranya always changed her directions by using every opportunity that came in her way to make her strengths better. Their paths may be different but they all believed in only one philosophy in life that is never assuming they are weak. They didn't fight with their weakness all time but they made their strengths rule over their weakness. 


\section{REFERENCES}

[1] Clarke, M. (2008). Plodders, pragmatists, visionaries and opportunists: Career patterns and employability. Career International, 14(1), 8-28.

[2] Hoff, K.S. Leaders and managers: Essential skills required within higher education. Higher Education 38, 311-331 (1999)

[3] Klegeris, A., McKeown, S.B., Hurren, H. et al. Dynamics of undergraduate student generic problem-solving skills captured by a campus-wide study. High Educ 74, 877-896 (2017).

[4] Tran, T.T. Limitation on the development of skills in higher education in Vietnam. High Educ 65, 631-644 (2013). 